\title{
Can mares be classified as resistant or susceptible to recurrent endometritis?
}

\author{
J.F. Pycock ${ }^{1}$, D. Paccamonti ${ }^{2}$, H. Jonker ${ }^{3}, J$. Newcombe ${ }^{4}$, G. van der Weijden ${ }^{3}$ and M. Taverne ${ }^{3}$ \\ Equine Reproductive Services, Howe Farm Cottage, Old Malton, North Yorkshire, IJK \\ Dept. of Veterinary Clinical Sciences, Louisiana State University, USA \\ Department of Herd Health and Reproduction, University of Utrecht, The Netherlands \\ Warren House Farm, Brownhills, West Midlands, UK
}

\begin{abstract}
Summary
To evaluate the efficacy of oxytocin as a treatment for persistent post-breeding endometritis, a large clinical study was performed using 1,267 mares. The aim of the study was to assess the effect of three different treatments on pregnancy rate in mares. All mares were bred and allocated, in strict rotation, to one of four treatment groups: 1) non-treated controls; 2) intrauterine infusion of broad-spectrum antibiotics; 3) intravenous oxytocin injection; 4) intravenous oxytocin injection followed by intrauterine antibiotics. Pregnancy status of mares was determined at $13-15$ days and $27-30$ days post ovulation using ultrasonography. The pregnancy rate of Group 4 (72\%) was higher than that of Group $2(64 \% ; P<0.01)$ or Group $3(63 \% ; P<0.01)$. The pregnancy rates of Groups 2 and 3 were similar $(P>0.80)$ and higher than that of Group $1(56 \% ; P<0.01)$. Antibiotics and oxytocin appeared to have an additive beneficial effect which suggested two different modes of ac tion of the combination treatment, namely antibacterial activity and fluid drainage. In non-treated mares more fluid accumulated in the uterine lumen after mating which was the most likely reason for the reduced pregnancy rates in this Group.
\end{abstract}

Keywords: $\quad$ mare, intrauterine fluid, endometritis, pregnancy rate, oxytocin

\begin{abstract}
Können Stuten hinsichtlich ihrer Endometritisanfälligkeit als resistent oder empfänglich klassifiziert werden?
Um die Effizienz von Oxytocin zur Behandlung der persistierenden durch die Belegung bedingten Endometritis zu ermitteln, wurde eine umfangreiche klinische Studie auf der Basis von 1267 Stuten durchgeführt. Das Ziel der Studie war, den Effekt von drei verschiedenen Behandlungsmethoden auf die Trächtigkeitsrate der Stuten zu untersuchen. Alle Stuten wurden belegt und in rotierender Reihenfolge einer der vier Untersuchungsgruppen zugeordnet: 1. nicht behandelte Kontrollen, 2. intrauterine Infusion eines Breitbandantibiotikums, 3. intravenöse Oxytocin-Injektion. 4. intravenöse Oxytocin-Injektion mit anschließender intrauteriner Antibiotikagabe. Die Trächtigkeitsuntersuchung erfolgte ultrasonographisch am 13-15. und 27.-30. Tag post ovulationem. Die Trächtigkeitsrate der Gruppe 4 (72\%) war höher als die der Gruppe 2 $(64 \%, p<0,01)$ oder der Gruppe $3(63 \%, p<0,01)$. Die Trächtigkeitsraten der Gruppen 2 und 3 waren gleich ( $p>0,8)$ und höher als die der Gruppe $1(56 \%, p<0,01)$. Antibiotika und Oxytocin scheinen einen sich addierenden günstigen Effekt zu haben. Dies läßt auf zwei verschiedene Wirkungsmechanismen der Kombinationstherapie schließen: der antibakterielle Effekt und die Flüssigkeitsdrainage. Bei den unbehandelten Stuten traten nach der Bedeckung größere Flüssigkeitsakkumulationen im Uterus auf, was wahrscheinlich den Grund für die vermin derte Trächtigkeitsrate in dieser Gruppe darstellt.
\end{abstract}

Schlüsselwörter Stute, intrauterine Flüssigkeit, Endometritis, Trächtigkeitsrate, Oxytocin

\section{Introduction}

Following the transient endometritis which is an inevitable sequel to breeding (Ricketts and Mackintosh 1987), some mares suffer from a persistent endometritis (Liu and Cheung 1986; Allen and Pycock 1988) which is a major cause of reduced fertility (Asbury 1992). Such mares have traditionally been classified as susceptible to endometritis. In the last few years it has become evident that physical clearance of uterine fluid is the critical factor in uterine defence (Evans et al. 1986; Allen and Pycock 1988; LeBlanc et al. 1989; Troedsson and Liu 1991) and any impairment of this function renders a mare susceptible to persistent endometritis (Allen 1993)

Oxytocin was suggested for the treatment of mares susceptible to endometritis by Allen in 1991 and at the first In- ternational Endometritis Meeting, Pycock described its successful use as part of a therapeutic programme in a group of mares barren for various times (Pycock 1993a; Pycock 1994). However, no untreated control mares were included in this study. At the same time LeBlanc (1994) reported that oxytocin enhanced uterine clearance and suggested it may be useful for mares with impaired clearance. It appeared that oxytocin was beneficial for the treatment of endometritis, but a large controlled study with critical evaluation of therapeutic protocols seemed essential to ensure that, unlike the myriad of other treatments for endometritis, the effectiveness of oxytocin was thoroughly investigated in a controlled manner. By using a large number of mares in normal clinical practice the use of an endometritis model 
was avoided. The hypothesis of the study was that intrauterine antibiotics and oxytocin given alone or in combination improve pregnancy rates when given after breeding.

\section{Materials and methods}

Mares

Maiden, barren and post-parturient mares of Thoroughbred $(n=574)$, hunter (crossbred) $(n=647)$ and pony $(n=46)$ types resident on 19 studfarms in the United Kingdom, were examined as described below. The age of the mares ranged from 3-22 years and the examinations took place during the period February to September 1993. The study was performed working with two separate mare populations.

\section{Experimental protocol}

Gynaecological examinations: The genital tract was evaluated by both palpation and real-time, B-mode ultrasonography using a $5 \mathrm{MHz}$ linear array transducer (Concept 500; Dynamic Imaging, Livingston, Scotland; Author 1) and a multifrequency ( 3 to $7 \mathrm{MHz}$ ) convex array transducer (Imager 3; Diagnostic Sonar Ltd, Livingston. Scotland; Author 2). During oestrus, and until 4 days after ovulation, mares were examined every 48 hours. The presence and size of all follicles of more than $20 \mathrm{~mm}$ in diameter and all luteal structures were recorded. Ovulation was diagnosed by follicle disappearance and the presence of an early corpus luteum (CL) as determined by both palpation and ultrasonic imaging.

Pregnancy examination: Pregnancy was determined by ultrasonographic examination of the uterus on the 13th, 14th or 15th day after ovulation. A positive diagnosis of pregnancy was based upon the identification of an embryonic vesicle. The shape, size and position of all endometrial or lymphatic cysts, which could be confused with embryonic vesicles, were recorded before the first examination for pregnancy. Ultrasonographic examination of the uterus of pregnant mares was repeated between 27 and 30 days after ovulation. Embryonic loss was defined as the disappearance of the embryonic vesicle between the first and second examinations for pregnancy.

\section{Experimental design}

Once in oestrus, all mares were allocated to one of four treatment groups at the examination after mating. The authors had no influence over the order in which mares were presented for examination. Group assignment was by strict rotation.

The treatment groups were as follows:

Group 1: No treatment

Group 2: Antibiotic treatment within 72 hours after mating.

Author 1(JFP): A water-soluble mixture of neomycin (1 g), polymixin B (40,000 i.u.) and furaltadone (600 mg) (Utrin; Univet, Bicester, England) with crystalline benzylpenicillin (5 Mega/3 g) (Univet) was dissolved in $20 \mathrm{ml}$ of sterile water and instilled into the uterus via a sterile catheter. No attempt was made to dilate the cervix during passage of the catheter.

Author 2 (JN): A suspension of $1200 \mathrm{mg}$ procaine penicillin and $1500 \mathrm{mg}$ dihydrostreptomycin (Penillin PS Injection; Univet) and $900 \mathrm{mg}$ framycetin solution (Framomycin 15\% Injection; C-Vet, Bury St. Edmunds, UK). The total volume was $12 \mathrm{ml}$ and the antibiotic combination was loaded into a $15 \mathrm{ml}$ centre-nozzle syringe. The cervical canal was explored digitally and the barrel of the syringe passed alongside the finger until the flange was on the level of the external os. The antibiotic could then be instilled into the posterior uterine body.

Group 3: Oxytocin treatment within 72 hours after mating. 25 i.u. oxytocin (Oxytocin Leo; Leo Laboratories, Aylesbury, England) was given by intravenous injection.

Group 4: Antibiotics and oxytocin treatment within 72 hours after mating. The treatment regime was the same as in Group 3 except that there was the addition of an antibiotic infusion (as for Group 2) 30 minutes after oxytocin injection.

Data were collected only from the oestrous cycle at which the mare was first mated. The time from treatment after mating varied, but all treatments were given within 72 hours after mating. Mares that had not ovulated within 96 hours after mating were removed from the experiment.

Overall pregnancy rates were determined for each treatment group.

\section{Statistical analyses}

The study involved both categorical data and non-categorical data. The pregnancy rates were categorical data i.e. a mare was pregnant or non-pregnant and the two possible outcomes were mutually exclusive. The association between treatment and pregnancy was assessed using Chisquared analysis (Snedecor and Cochran 1980) and a Statistix 4.1 (Extended Dos version) programme (University of Utrecht). Calculation of a probability $(P)$ value was used as a significance test. The results for fluid-volume were noncategorical data and were analysed using 2-way analysis of variance and the method of least significant difference. A probability level of $\mathrm{P}<0.05$ was considered statistically significant.

\section{Results}

\section{Pregnancy rates}

Each of the three treatments resulted in a significant $(P<0.01)$ increase in pregnancy rate compared with the untreated control mares (Figures 1 and 2) for both authors. There was no statistical difference in pregnancy rate between Group 2 (intrauterine antibiotics) and Group 3 (intravenous oxytocin) mares. Mares in Group 4 (intrauterine antibiotics and intravenous oxytocin) showed a higher $(P<0.05)$ pregnancy rate than either Group 2 or Group 3 mares.

Embryonic loss between first and second examinations for pregnancy was not statistically different $(P>0.05)$ between 
groups for either author (Figures 1 and 2), although it was higher for author 2 throughout.

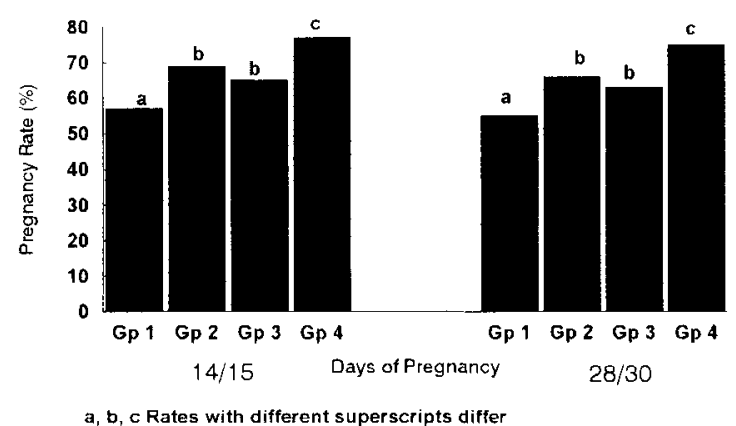

Fig. 1: Pregnancy rates for 380 mares in the four different treatment groups (Author 1) ( $\mathrm{n}=95 /$ group)

Trächtigkeitsrate für 380 Stuten in den 4 verschiedenen Behandiungsgruppen (Autor 1) ( $n=95 /$ Gruppe).

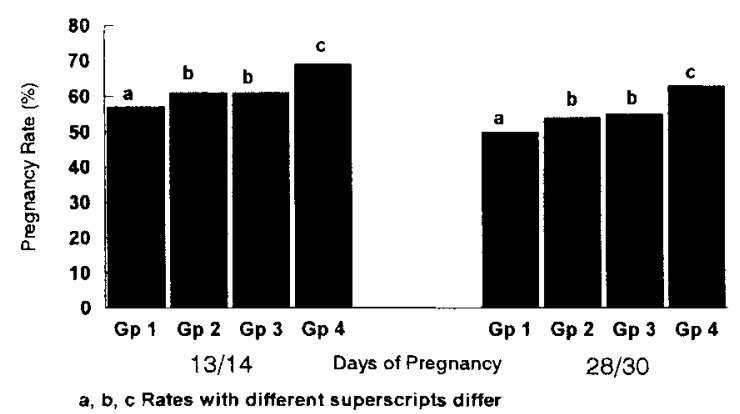

Fig. 2: Pregnancy rates for 887 mares in the four different treatment groups (Author 2 ) ( $n=227 /$ group $1 ; n=222 /$ group 2; $n=221 /$ group $3 ; n=219$ group 4)

Trächtigkeitsrate für 887 Stuten in den 4 verschiedenen Behandlungsgruppen (Autor 2$)(n=227 /$ Gruppe1; $n=222$ / Gruppe 2; $n=221 /$ Gruppe 3; n=219 Gruppe 4).

\section{Discussion}

The results of this study, reported in more detail in Pycock and Newcombe (1996), have shown the benefits of treatments which either cause the elimination, or reduce the production, of intrauterine fluid, on pregnancy rate in a large group of mares.

Pregnancy rates were highest in the mares given intrauterine antibiotics as well as oxytocin (Group 4). This suggests two different modes of action, namely antibacterial activity and fluid drainage, which were additively helpful. Antibacterial activity may be linked to reduction of intraluminal fluid since, in those mares that were treated with oxytocin alone, some bacteria remained within the uterine lumen and presumably the inflammatory effects of these bacteria caused fluid to accumulate again. Pycock and Allen (1990) found that the equine uterus responds within 30 minutes to bacterial infusion, with the accumulation of inflammatory exudate in the uterus. Presumably the antibiotics reduced fluid production through their an- timicrobial action which reduced bacterial numbers and, therefore, the stimulus to produce fluid. Another possible explanation for the success of the combination of treatments is that not all mares in this study which were susceptible to endometritis have impaired uterine clearance. It is important to remember that in certain mares, local immune deficiencies play a role in the development of persistent uterine infection.

Oxytocin is not a wonder drug for endometritis, but there is clearly an advantage in its combination with intrauterine antibiotics. Allen (1991) first suggested that post-mating treatment with oxytocin may assist in the clearance of intraluminal uterine fluid and does not adversely affect pregnancy rates; this is the first large clinical study to support this suggestion.

In designing the trial there appeared to be two alternatives:

1) Only treat mares defined as 'susceptible' to recurrent endometritis with 25\% untreated controls;

2) Treat the whole population without reference to previous history or clinical investigation.

The problem with the first approach is that the criteria used to detect susceptible mares varies among researchers and may be based on response to bacterial challenge; reproductive history including endometrial biopsies and/or cytology and culture results; demonstration of uterine clearance failure and ultrasound detection of free luminal fluid. Even if valid, these methods may not be applicable to field studies using large numbers of mares often with an unknown breeding history. Furthermore, there is an enormous range in susceptibility to endometritis: some mares need no post-breeding treatment to become pregnant while others need extensive post-breeding therapy. Fluid accumulation is frequently seen in maiden mares, particularly if they are above 10 years of age. Impaired uterine drainage due to abnormal cervical function is important in the aetiology of susceptibility to endometritis (Pycock 1993b), however, by conventional assessment these mares may have an endometrial biopsy, culture and/or cytology placing them in the category of resistant mares.

Therefore it is suggested that for large field studies investigating therapeutic strategies for persistent post-breeding endometritis, the optimal approach may be to treat the whole mare population without reference to previous history or clinical investigation and include an untreated control group of mares. Due to the large numbers involved in such studies, each group would likely include a similar number of mares highly susceptible, slightly susceptible or resistant to persistent endometritis and thus the need to define 'susceptible' can be avoided. While it would be useful to determine the mares status in regards to endometritis (reproductively normal versus mares with a delay in uterine clearance), for those working with large numbers of broodmares under field conditions, this is an impossible goal at this moment in time.

For studies involving smaller numbers, in view of the importance of uterine fluid accumulation, the detection of 
uterine fluid more than 24 hours after breeding may assist categorisation of mares into resistant and susceptible. This breeding challenge may be a useful addition to attempting to categorise mares as resistant or susceptible to endometritis.

In conclusion, the whole population of a large number of mares was used without reference to previous history or clinical investigation. By following this „no selection" protocol each of the four groups included a similar number of mares with differing degrees of susceptiblity to endometritis. Consequently a large number of mares not susceptible to endometritis were treated due to the experimental design and the results obtained should not be interpreted as indicating that it is desirable to treat every mare routinely after mating regardless of clinical findings. Only mares with impaired uterine clearance should be treated to avoid potential adverse side-effects. The difficulty in practice is to identify these mares as signs such as post-mating uterine fluid are not always present in mares susceptible to endometritis.

\section{References}

Allen, W.E. (1991): Investigations into the use of exogenous oxytocin for promoting uterine drainage in mares susceptible to endometritis. Veterinary Record 128, 593-594.

Allen, W.E. and Pycock, J.F. (1988): Cyclical accumulation of uterine fluid in mares with lowered resistance to endometritis. Veterinary Record 122, 489-490.

Allen, W.E. and Pycock, J.F. (1989): Current views on the pathogenesis of bacterial endometritis in mares with lowered resistance to endometritis. Veterinary Record 125, 298-301.

Allen, W.R. (1993): Conclusion to the J.P. Hughes endometritis Conference. Equine Veterinary Journal 25, $184-193$.

Asbury, A.C. (1992): How effective is your treatment of bacterial endometritis? Equine Veterinary Journal 24, 416-417.

Evans, M.J., Hamer, J.M., Gason, L.M., Graham, C.S., Asbury, A.C. and Irvine, C.H.G. (1986): Clearance of bacteria and non antigenic markers following intrauterine inoculation into maiden mares: effect of steroid hormone environment. Theriogenology 26, 37-50.

LeBlanc, M.M. (1994): Oxytocin - The new wonder drug for treatment of endometritis. Equine Veterinary Education $6,39-43$
LeBlanc, M.M., Asbury, A.C. and Lyle, S.K. (1989): Uterine clearance mechanisms during the early postovulatory period in mares. American Journal of Veterinary Research 50, $864-867$.

Liu, I.K.M. and Cheung, A.T.W. (1986): Immunoglobulin and neutrophil defence against uterine infection in mares resistant and susceptible to chronic endometritis: A review. Journal of the American Veterinary Medical Association 189, 700 - 702.

Pycock JF (1993a): Early mating, intrauterine treatment and oxytocin. Equine Veterinary Journal 25, 192-193

Pycock JF (1993b): Cervical function and uterine fluid accumulation in mares. Equine Veterinary Journal 25, 191

Pycock, J.F. (1994): A new approach to treatment of endometritis. Equine Veterinary Education 6, 36 - 38.

Pycock, J.F. and Allen, W.E. (1990): Inflammatory components in uterine fluids from mares with experimentally induced bacterial endometritis. Equine Veterinary Journal 22, 422 - 425.

Pycock, J.F. and Newcombe, J.R. (1996): Assessment of the effect of three treatments to remove intrauterine fluid on pregnancy rate in the mare. Veterinary Record 138, 320-323.

Ricketts, S.W. and Mackintosh, M.E. (1987): Role of anaerobic bacteria in equine endometritis. Journal of Reproduction and Fertility Supplement 35, $343-351$.

Snedecor, G.W. and Cochran, W.G. (1980): Statistical Methods. Iowa, The lowa State University Press.

Troedsson, M.H.T. and Liu, I.K.M. (1991): Uterine clearance of nonoantigenic markers $(51 \mathrm{Cr})$ in response to a bacterial challeneg in mares potentially susceptible and resistant to chronic uterine infections. Journal of Reproduction and Fertility Supplement 44, 283 288.

\section{Acknowledgements}

The authors would like to thank the management and staff of the studfarms and the mare owners for their enthusiastic assistance with these very time-consuming procedures.

\section{Dr. J.F. Pycock}

Howe Farm Cottage

Old Malton

North Yorkshire

YO17 ORG, UK

Tel: 0044-1653-698185

Fax: 0044-1653-690939

e-mail 73410.3433@compuserve.com 